\title{
Impact of the Worst School Experiences in Students: A Retrospective Study on Trauma ${ }^{1}$
}

\author{
Paloma Pegolo de Albuquerque ${ }^{2}$ \\ Universidade Federal de São Carlos, \\ São Carlos-SP, Brazil
}

\author{
Lucia C. A. Williams \\ Universidade Federal de São Carlos, \\ São Carlos-SP, Brazil
}

\begin{abstract}
The literature indicates damage to students' mental health in cases of school violence. The aim of this retrospective study was to evaluate the psychological impact of school victimization in university students, and to analyze the association between PTSD symptoms and variables related to school victimization. 691 University students responded to the Portuguese version of the Student Alienation and Trauma Survey (SATS). Clinically significant scores in the subscales ranged from 4.7\% (somatic symptoms) to $20 \%$ (hypervigilance), with frequent symptoms described in the literature resulting from school victimization, such as depression, hopelessness, cognitive difficulties, and traumatic event recollection. Additionally, $7.8 \%$ of participants presented PTSD symptoms after suffering their "worst school experience". Associations were found between PTSD symptoms and the level of distress after the experience, as well as the perceived benefits after the event, and duration. The results confirm the potential detrimental effects of school victimization, and may be useful to further investigations on this topic.
\end{abstract}

Keywords: school violence, emotional trauma, post-traumatic stress disorder

\section{Impacto das Piores Experiências Escolares em Estudantes: Um Estudo Retrospectivo Sobre Trauma}

\begin{abstract}
Resumo: A literatura indica a existência de danos para a saúde mental de estudantes em casos de violência no contexto escolar. O objetivo deste estudo retrospectivo foi avaliar o impacto psicológico da vitimização escolar em estudantes universitários e analisar a associação dos sintomas de TEPT com variáveis relacionadas à vitimização. No total, 691 estudantes universitários responderam à Escala sobre Experiências Traumáticas em Estudantes. Escores clinicamente significativos nas subescalas variaram de 4,7\% (sintomas somáticos) a 20\% (hipervigilância), sendo frequentes sintomas descritos na literatura resultantes de vitimização, como: depressão, desesperança, dificuldades cognitivas e rememoração do evento traumático. Adicionalmente, 7,8\% apresentaram sintomas de TEPT após a sua pior experiência escolar. Foram encontradas associações entre os sintomas de TEPT e o incômodo sentido após a experiência, benefícios percebidos após o evento e duração do mesmo. Tais dados indicam o potencial nocivo das experiências de vitimização escolar, podendo contribuir para futuras pesquisas em tal área.
\end{abstract}

Palavras-chave: violência escolar, trauma emocional, transtorno de stress pós-traumático

\section{Impacto de las Peores Experiencias en la Escuela en Estudiantes: Un Estudio Retrospectivo Sobre Trauma}

\begin{abstract}
Resumen: La literatura indica que casos de violencia en el contexto escolar causan daños a la salud mental de los estudiantes. El objetivo de este estudio retrospectivo fue evaluar el impacto psicológico de la victimización escolar en estudiantes universitarios y analizar la asociación de los síntomas de TEPT con variables relacionadas a la victimización. Un total de 691 estudiantes universitarios respondieron a la Escala de Experiencias Traumáticas en los Estudiantes. Puntuaciones clínicamente significativas en las subescalas oscilaron entre el 4,7\% (síntomas somáticos) y el 20\% (hipervigilancia), y se encontraran síntomas frecuentes descritos en la literatura resultante de victimización, tales como: depresión, desesperanza, problemas cognitivos y recuerda excesiva del evento traumático. Además, el 7,8\% tenía síntomas de TEPT un mes después de su peor experiencia escolar. Se encontraran asociaciones con los síntomas de TEPT y el malestar que se siente después de la experiencia; beneficios percibidos después del evento y su duración. Los resultados indican el potencial nocivo de las experiencias de victimización escolar y pueden contribuir a investigaciones futuras.
\end{abstract}

Palabras clave: violencia escolar, trauma emocional, transtorno por estrés postraumático

Violence is present in schools in different ways, ranging from serious assaults to acts of incivility (Cubas, 2007). Such

\footnotetext{
1 Support: São Paulo Research Foundation (FAPESP - Protocol no. 2010/01379-5)

${ }^{2}$ Correspondence address:

Paloma Pegolo de Albuquerque. Rua Guatemala, 166, Vila Brasília. CEP

13566-720. São Carlos-SP, Brazil. E-mail: palomanier@yahoo.com.br
}

acts may involve various school agents, such as students, employees, administrators, and teachers. The literature suggests that school peer victimization is a risk factor for the development of psychosocial problems, such as: academic problems (Orpinas \& Horne, 2006) or cognitive difficulties (Houbre, Tarquinio, Thuillier, \& Hergott, 2006); loneliness (Orpinas \& Horne, 2006); decreased self-esteem (Orpinas \& Horne, 2006) or negative self-concept (Houbre et al., 2006); 
behavioral problems or aggression (Houbre et al., 2006); and feeling unsafe at school (Felix, Furlong, \& Austin, 2009).

Furthermore, victimized individuals are more likely to present: psychosomatic symptoms (Fekkes, Pijpers, Fridriks, Vogels, \& Verloove-Vanhorick, 2010; Gini \& Pozzoli, 2009; Houbre et al., 2006); internalizing mental health problems (Luukkonen, Rasanen, Hakko, \& Riala, 2010), as anxiety (Bond, Carlin, Thomas, Rubin, \& Patton, 2001; Houbre et al., 2006; Luukkonen et al., 2010), and depression (Bond et al., 2001; Felix et al., 2009; Luukkonen et al., 2010); as well as psychiatric symptoms in general (Houbre et al., 2006). While there are still few studies evaluating the consequences of long-term peer victimization or its long-term effects (Idsoe, Dyregrov, \& Idsoe, 2012), research shows it to be a risk factor for the development of long-term consequences, such as psychiatric symptoms in general (Sourander et al., 2009), depression (Hemphill et al., 2011), and suicidal ideation (Schafer et al., 2004).

In addition to peer victimization, students may also suffer victimization by teachers or school staff, although there are fewer studies on this topic. In terms of the Brazilian reality, Stelko-Pereira, Santini and Williams (2011) collected data on 396 students from two public schools in a vulnerable neighborhood, finding that, in the six months prior to the survey, $1.6 \%$ of students responded that they had suffered physical abuse by staff at one school, and $12.2 \%$ identified the same type of victimization in the second school. Victimized students had a higher proportion of females who were bullies and victims of bullying, with higher rates of depression than students not physically victimized by teachers.

Besides the commonly described symptoms, the literature has shown that individuals victimized by peers may also develop Post-Traumatic Stress Disorder symptoms (PTSD) (Albuquerque, Williams, \& D'Affonseca, 2013; Crosby, Oehler, \& Capaccioli, 2010; Idsoe et al., 2012; Storch $\&$ Esposito, 2003). However, there are few studies clarifying how the relationship between these two variables occurs (Idsoe et al., 2012; McKenney, Pepler, Craig, \& Connoly, 2005; Mynard, Joseph, \& Alexander, 2000).

The Diagnostic and Statistical Manual of Mental Disorders: DSM-IV and DSM-5 (American Psychiatric Association, 2002, 2013) identify traumatic events related to the development of PTSD as situations involving threat of death or physical integrity. This definition would exclude school violence victims of presenting PTSD symptoms, a position that has been questioned by clinicians and researchers (Ateah \& Cohen, 2009). Overall, there is considerable controversy about the adequacy of PTSD current diagnostic criteria, because there is evidence that everyday events that individuals experience may be potentially traumatic (Kristensen, Parente, \& Kaszniak, 2005). Moreover, it is questionable whether the indirect exposure to various types of stressful events, as witnessing episodes of violence, for example, may lead to PTSD (Salter \& Stallard, 2008). As a result, the understanding of a traumatic event has been constantly revised and, according to Figueira and Mendlowicz (2003), the emphasis of research has shifted from external to internal or subjective factors, so that the emotional responses to the event receive more attention.
According to Idsoe et al. (2012), in some cases of peer victimization, children may evaluate the event as threatening to their basic safety, considering it a source of real stress. Ateah and Cohen (2009) add that students may perceive school victimization as an event that causes intense fear, horror and hopelessness, classifying it as uncontrollable (Newman, Holden, \& Delville, 2011). Idsoe et al. remind us that school violence may be particularly harmful as it occurs in a period when the brain is forming biopsychosocial systems that regulate behavior.

Some studies have investigated the relationship between peer victimization and the development of PTSD symptoms, indicating the correlation between those events: Idsoe et al. (2012) conducted a study with 963 Norwegian students of grades 8-9 finding that $33.7 \%$ of students who had experienced bullying showed significant scores for PTSD. Crosby et al. (2010) conducted a study with 24410 to 14 year-old students in the United States. The results showed that physical, verbal and relational victimization were positively correlated to post-traumatic stress symptoms. Additionally Storch and Esposito (2003) investigated the development of PTSD symptoms after peer victimization in 205 children with a mean of 10.8 years in the same country, realizing that direct and relational victimization were significant and positively associated to PTSD symptoms.

Mynard et al. (2000) conducted a study in England with 331 children and adolescents, aged 8-11 years, and the data suggest that about one third of the children who had suffered bullying may present significant levels of post-traumatic stress. McKenney et al. (2005) surveyed 1041 students, with a mean age of 11.9 years in Canada, noting that the likelihood of having significant symptoms of PTSD in those who reported any victimization was 2.23 times higher than in those without victimization. Additionally, the likelihood of having significant symptoms of PTSD for students who reported severe victimization was 13.98 times greater than for those without victimization.

Regarding retrospective studies involving school victimization and PTSD, Ateah and Cohen (2009) conducted a survey with 1007 US University students and 210 Canadian students who responded to the instrument Student Alienation and Trauma Survey (SATS), by Hyman and Snook (2002), realizing that about $8 \%$ of the Canadian sample and $10 \%$ of the American reached DSM-IV criteria for PTSD. Almost $0.5 \%$ of each sample obtained extreme scores for PTSD. Verbal and relational aggression were the events most remembered as worst school experiences, indicating that they may lead to profound negative effects on mental health. In a similar study conducted with 1007 American, and 373 English University students using the SATS instrument, Kay (2005) realized that $2.9 \%$ of participants from the United States and 3.9\% from England showed significant scores for PTSD; additionally, 5.3\% from the United States, and 2.8\% from England had above average scores, which is considered risk for the development of PTSD.

McGuckin, Lewis, Cummins and Cruise (2011) conducted a study using the SATS with 154 University students, aged 17 to 55 years (mean 24.2 years), in Ireland, 
investigating negative school experiences and their arising symptoms. The main result was that $25.6 \%$ of participants had scores above the cut-off scores for PTSD: 19.4\% had high scores, and $6.2 \%$ had clinically significant scores. All authors of studies using the SATS instrument concluded that severe cases of school victimization may precede or be related to PTSD, and many school children may experience school victimization as a traumatic event.

Considering the absence of data on school victimization and trauma symptoms in the Brazilian literature, the aim of this study was to evaluate the psychological impact of school victimization in a sample of university students. To this end, we sought to investigate the student proportion that had traumatic symptoms in general, and, in particular, those who have attained PTSD criteria after the Worst School Experience (WSE). Additionally, we sought to examine the association of PTSD symptoms to variables related to the WSE, namely: distress level after the worst school experience, perceived benefits of the negative experience, duration of the worst experience, and school victimization in general.

\section{Method}

\section{Participants}

Participants were 691 students from a public University in a mid-size city in Brazil. The sample constituted 9.4\% of the 7,369 students enrolled in undergraduate courses at the University in the semester in which the study was conducted. A fair representation of participants was attempted, taking in consideration all courses from different areas of the University, involving at least one course from each of the 34 undergraduate available programs. Approximately $95 \%$ of the students invited to participate accepted to take part of the study. Participants had a mean age of 21.1 years, ranging from 17-61 years (SD: 3.48 ); $54.8 \%$ were female and $45.2 \%$ male. Regarding ethnicity, $77 \%$ of students identified themselves as white; $4.3 \%$ as black; $12.3 \%$ brown; $5.5 \%$ Asian; $0.6 \%$ chose the option "other"; and $0.3 \%$ did not answer. Participants rated their family income as thus: $43 \%$ considered themselves "Slightly better than most"; $33.1 \%$ "Similar to other homes"; $20.7 \%$ "Much better than most"; $2.6 \%$ "Slightly worse than most"; and only $0.6 \%$ "Much worse than most". These questions are part of the SATS-R instrument and provide a subjective assessment of income.

\section{Instruments}

The Student Alienation and Trauma Survey - $R$ (SATS-R) is an American retrospective instrument developed by Hyman and Snook (2002). The version used in the present study was translated and adapted (content validity) to Brazil by Albuquerque and Williams (2014), being subsequently named Escala sobre Experiências Escolares Traumáticas em Estudantes (ExpT) or School Traumatic Experience in Students Scale. The instrument's initial questions provide for the collection of socio-demographic data, such as: gender, ethnicity, income and parental education level. Then the
SATS-R is divided into two parts. Part I contains a list of 58 traumatic events that may occur at school, information of the frequency they occurred, and questions about the WSE.

Part II of the instrument is comprised of a list of 105 possible symptoms associated with stress developed after the worst experience, and, for each of these symptoms, their frequency and duration is identified, in a six unit Likert scale, ranging from Never to All the time. The manual for the SATS instrument (Hyman \& Snook, 2002) presents 11 subscales, which generate scores and allow the indication of clinically significant symptoms, four of which were items based on the DSM-IV Manual (American Psychiatric Association, 2002), corresponding to the criteria for PTSD diagnosis: Impact of the event (IMPACT) - describes agitated and disorganized behaviors that are often observed in young people who have experienced trauma; Re-experience of the Trauma (REEX); Avoidance and Numbing (AVOID) - avoidance of places where the traumatic event occurred, avoidance of the stimuli associated with the event, thoughts and feelings about the experience; Increased Arousal (AROUS) - increased physiological arousal, interfering with the ability of concentration and relaxation. The other symptom subscales assess the presence and intensity of stress-related symptoms: Depression (DEPR); Hopelessness (HOPELS); Somatic Symptoms (SOM) - such as stomach problems, loss of appetite and others; Oppositional Conduct (OPP) - a recurring pattern of oppositional behavior, defiant, disobedient and hostile behavior toward authority figures; Hypervigilance (HYPER) - state of excessive alert, which manifests itself in a constant investigation of environment to detect danger signals; Dissociation and Dreams (DISSOC) dissociative lapses, disturbing dreams or temporary alteration of consciousness not due to organic mental illness; and General Maladjustment (MAL) - which refers to the variety of clinical symptoms that may occur in traumatized youngsters. In addition to these subscales, the manual provides norms to PTSD suggestion.

\section{Procedure}

Data collection. The instrument application was collectively performed at the University during classes. The instructions given to participants were standardized. Data collection lasted about 40 minutes per class and was conducted by the first author.

Data analysis. A database was compiled after data collection. Descriptive statistics were used to identify participant's demographics data, the WSEs, as well as their duration and frequency, and the symptoms developed after the WSE. The correction and interpretation of the SATS-R generate a Total Score (TOTAL), which is a global measure, involving all symptoms of stress experienced by the participant, as well as a summary of the stress symptoms. The indication of categories according to the scores on the traumatic symptoms subscales involve: low, average, and above average scores, and PTSD symptom suggestion (clinically significant; high indication; and extreme value). The programs Statistical Analysis System (SAS) and 
Statistical Package for the Social Sciences (SPSS) were used to perform statistical analysis ( $X^{2}$ Association Test and Multivariate Analysis of Variance - MANOVA). The significance level used in the tests was $5 \%(p<.05)$.

\section{Ethical Considerations}

The study was approved by the Institutional Review Board of the Universidade Federal de São Carlos (Certificate no. 277/2010). Participants had the option of providing an email address and/or telephone number for researchers to contact them, if needed. Thus, severe clinical cases of PTSD or depression received an individual session with the first author, after data analysis, and were referred to psychological services.

\section{Results}

\section{Worst School Experiences (WSE)}

The percentage of victimization modalities reported was: relational violence (at least one item reported by $85.2 \%$ of participants); verbal violence (77.7\%); physical violence (50.8\%); unfair discipline (43.1\%); property damage (33.4\%); witnessing violence (27.9\%); and sexual violence (21.4\%). Most students (84.8\%) identified their worst experience, divided into the categories: relational violence (indicated by $35.7 \%)$; verbal violence $(27.4 \%)$; physical violence $(12.9 \%)$; unfair discipline $(10.8 \%)$; witnessing violence (4.8\%); sexual violence (2.4\%); damage to property (2.2\%); and others (3.8\%). About the duration of the WSE, $32.1 \%$ said that the "worst experience" lasted only "one day"; 19.4\% "days or weeks"; $22.6 \%$ "months"; $8.4 \%$ "one year" and $10.5 \%$ reported that it had endured "years" (ranging from 2-8 years); and $6.5 \%$ did not answer this question. Further details on the worst experiences and other related variables might be found in Albuquerque (2014).

\section{Symptoms Developed After the Worst School Experience (WSE)}

Most participants (383 or 55.4\%) reported having been "Greatly disturbed" by the WSE; 246 (35.6\%) were "Somewhat disturbed"; 47 (6.8\%) were "not disturbed"; and $15(2.2 \%)$ did not answer the question. With regards to the subscales, Table 1 summarizes the most frequent items of the instrument identified by participants. The item most often identified was "I tried to stay away from the person who hurt me", pointed out by $53 \%$ of participants.

The SATS Manual (Hyman \& Snook, 2002) indicates PTSD symptom levels according to the scores on the traumatic symptoms subscales: low, average, above average and PTSD symptomatology indication (clinically significant, high indication and extreme value). The distribution of participants with PTSD symptom indication, according to the scores obtained on each of the subscales was: Somatic Symptoms (4.7\%), Impact of the Event (5\%), Oppositional Conduct (5.1\%), Re-experience of the Trauma (6.1\%), General Maladjustment (6.7\%), Depression (7.1\%), Increased Arousal (7.6\%), Hopelessness (8.6\%), Dissociation (8, 7\%), Avoidance and Numbing (12.1\%) and Hypervigilance (20\%).

Regarding the development of PTSD symptoms after the WSE, the SATS Manual (Hyman \& Snook, 2002), provides norms based on criteria from the DSM-IV (stressful and shocking event for the individual, re-experiencing symptoms, avoidance and numbing, and increased excitability), according to the scores obtained. Among participants, 280 (40.5\%) obtained "very low levels"; 117 (17\%) "below average"; 165 (23.9\%) "average values"; and 75 (10.8\%) were "above average". A total of 54 participants $(7.8 \%)$ had PTSD indication; 33 (4.8\%) had "clinically significant" scores; 14 (2\%) had "high indication" for PTS, and $7(1 \%)$ showed "extreme value" for PTSD. Furthermore, 10.8\% presented above average rates, a concerning factor according to the Manual, as these individuals would be at risk for

Table 1

SATS Items More Frequently Presented by Participants

\begin{tabular}{llr}
\hline Symptoms Subscales & \multicolumn{1}{c}{ Items } \\
\hline Avoidance and Numbing & I tried to stay away from the person who hurt me & 53 \\
Hypervigilance & I got very nervous about things & 52.1 \\
Increased Arousal & I kept an eye on others so I wouldn't get hurt again \\
Depression & I was not as happy as I used to be \\
Oppositional Conduct & I got very angry for no reason \\
Re-experience of the trauma & I thought about what happened even though I didn't want to \\
Hopelessness & I thought I was not as good a kid as I used to be \\
Impact of the Event & I found it hard to keep my mind on a task \\
Dissociation and Dreams & I had trouble making up my mind \\
Somatic Symptoms & I was more tired than I used to be \\
General Maladjustment & I wished I were a little kid again \\
\hline
\end{tabular}


future development of PTSD. Participants who had clinically significant scores indicated that such symptoms had lasted more than a month, which is a needed criterion to assess PTSD symptomatology (American Psychiatric Association, 2013).

\section{Other Variables Associated With PTSD}

An association between PTSD symptoms and level of distress reported by the participant after the WSE was found, in which as the distress level increased after the WSE, so did the likelihood of PTSD symptoms presentation $\left(X^{2}\right.$ (4) $=119.207, p<.001)$. Among individuals who had low PTSD scores: $4.8 \%$ said they were not disturbed after the WSE; $28.5 \%$ felt somewhat disturbed, and $22.3 \%$ felt greatly disturbed. In contrast, among those who had high scores, and thus, indicative of PTSD, all participants felt disturbed $(0.2 \%$ "somewhat disturbed" and 7.4\% "greatly disturbed").

Additionally, participants responded to a question regarding whether they had obtained gains after the WSE, describing such gains if affirmative. Of a total of 313 participants, $(45.3 \%)$ said they obtained something positive after the WSE, describing mainly that they had matured and gained learning experiences. A statistical analysis was performed to find out if there was a significant relationship between presenting PTSD symptoms and benefits perceived by students after the WSE. It was observed that participants who had more benefits after the WSE had fewer symptoms of $\operatorname{PTSD}\left(X^{2}(2)=13.808, p<.001\right)$.

An association between PTSD symptoms and the WSE duration was also found: as the experience duration increased, it was more likely for participants to display PTSD symptoms $\left(X^{2}(4)=88.544, p<.001\right)$. For example, among individuals who experienced the WSE for days, $1.3 \%$ had PTSD symptomatology; among those who lived for years, $5 \%$ had PTSD symptoms.

Finally, regardless of the WSE, individuals with PTSD symptoms presented more victimization experiences in general (relational, verbal, physical, and sexual violence, property damage, witnessing violence, and unfair discipline; aspects measured by the part I of instrument) than those without PTSD symptoms. To confirm that the differences between groups were significant, a multivariate analysis of variance was performed (MANOVA). As there was difference in group size and larger deviations were found in the lower group, Pillai's trace was employed as the statistical test. To identify in which types of victimization the difference between means was significant, multiple comparison tests were conducted using the Bonferroni correction.

Table 2 shows the mean comparison and standard deviations of participants for groups with PTSD symptoms and without PTSD symptoms, as well as the differences between the means and the p-value.

A statistical significance at $5 \%$ level for differences between groups was found, and the group of individuals with PTSD presented higher means in all types of victimization $(F$ $(7)=15.714, p<.001)$.

\section{Discussion}

In terms of the impact of the WSE for the students, participants described many psychological or psychiatric symptoms resulting from their victimization. The percentage of participants with clinically significant scores on the subscales ranged from $4.7 \%$ (somatic symptoms) to $20 \%$ (hypervigilance). Many of the resulting symptoms presented by participants after their WSE are commonly described in the literature as results from school victimization, such as: Depression (Bond et al, 2001; Felix et al, 2009; Luukkonen et al, 2010); hopelessness (Ateah \& Cohen, 2009; Mynard et al., 2000); psychosomatic symptoms (Fekkes et al, 2010;. Gini \& Pozzoli, 2009; Houbre et al., 2006); academic problems (Orpinas \& Horne, 2006); cognitive difficulties (Houbre et al., 2006); aggression (Houbre et al., 2006); suicidal ideation (Schafer et al., 2004); and recalling the traumatic event (Storch \& Esposito, 2003; Williams, D'Affonseca, Correia, \& Albuquerque, 2011). Data from the present study point to the potential trauma of aversive experiences at school and it is, therefore, important to pursue investigations on how common everyday events may have traumatic impact (Elklit \& Petersen, 2008; Salter \& Stallard, 2008).

Among the total of 691 participants, $7.8 \%$ reported PTSD symptoms. This result reinforces data from studies that argue that school victims may also develop PTSD

Table 2

Comparison of Groups With and Without PTSD Symptoms in Terms of the Mean Occurrence of Victimization Modalities

\begin{tabular}{|c|c|c|c|c|c|c|}
\hline \multirow[t]{2}{*}{ Victimization modality } & \multicolumn{2}{|c|}{$\begin{array}{l}\text { Without PTSD } \\
\quad(n=637)\end{array}$} & \multicolumn{2}{|c|}{$\begin{array}{l}\text { With PTSD } \\
\quad(n=54)\end{array}$} & \multirow{2}{*}{$\begin{array}{l}\text { Mean difference } \\
\text { between groups }\end{array}$} & \multirow{2}{*}{$p$} \\
\hline & $M$ & $S D$ & $M$ & $S D$ & & \\
\hline Relational violence & 4.14 & 3.03 & 8.46 & 3.74 & -4.323 & .000 \\
\hline Physical violence & 3.13 & 3.07 & 5.76 & 4.4 & -2.633 & .000 \\
\hline Verbal violence & 2.39 & 1.5 & 3.74 & 1.66 & -1.356 & .000 \\
\hline Sexual violence & 0.36 & 0.65 & 0.91 & 0.98 & -0.544 & .000 \\
\hline Unfair discipline & 1.54 & 1.42 & 2.02 & 1.61 & -0.488 & .016 \\
\hline Witnessing violence & 0.54 & 0.83 & 0.91 & 1.2 & -0.367 & .003 \\
\hline Property damage & 0.32 & 0.47 & 0.48 & 0.5 & -0.160 & .017 \\
\hline
\end{tabular}


symptoms (Crosby et al., 2010; Idsoe et al., 2012; Storch \& Esposito, 2003). In the PTSD literature, in general, albeit not specific on school violence, there are prevalence studies that may be useful to compare with the present data. Research investigating the prevalence of this disorder in the United States showed that $8 \%$ of the adult population is affected by PTSD (American Psychiatric Association, 2002). In the review of Ozer, Best, Lipsey and Weis (2003), the authors state that an epidemiological study performed by Kessler, Sonnega, Bromet, Hughes and Nelson (1995) showed that $7.8 \%$ of the population have PTSD at some point in life. When the focus is youngsters, according to Lipschitz, Rasmusson, Anyan, Cromwell and Southwick (2000), the PTSD prevalence indicated in the literature among adolescents and young adults ranges from $2 \%$ to $9.1 \%$. Elklit and Petersen (2008) also defend that adolescence is a risk period with considerable exposure to stressful events, and because $6-20 \%$ of the population will suffer from PTSD at some point in life, it is important that mental health professionals learn to identify adolescents at risk, and offer intervention when necessary. Unfortunately, there are no epidemiological data about PTSD in the general population in terms of Brazil.

Comparing the data obtained in this study with data from retrospective research that used the same instrument to measure school victimization impact $(7.8 \%$ of the sample showing symptoms of PTSD), present results were similar to those from other countries, such as the United States, Canada, Ireland and England with regards to the development of traumatic symptoms in school violence victims. For example, Ateah and Cohen (2009) showed that approximately $8 \%$ of the Canadian sample and $10 \%$ of the American sample reached the criteria for PTSD; and almost $0.5 \%$ of each respective samples obtained extreme scores for PTSD. Similarities were also found to the data presented by McGuckin et al. (2011), in which $6.2 \%$ of the Irish sample showed clinically significant scores for PTSD.

Nevertheless, as the instrument's authors point out, the resulting scores should not be used as a definitive PTSD diagnosis, but as part of its assessment (Hyman \& Snook, 2002). According to Schaefer, Kristensen and Wolf (2012), a clinical assessment should not focus on the PTSD diagnosis per se, but on the intensity and frequency of symptoms (because symptomatology occurs on a continuum), assessing, thus, the level of functioning, suffering and the social and occupational impact to the individual. Regardless of the diagnosis, high scores of PTSD indicate damage to individuals and the need for psychological support.

The data also suggest that, among all the participants, those who showed PTSD symptoms, compared to those without symptoms, had a more negative perception of their WSE: they were greatly disturbed by the experience and did not perceive benefits derived from them. Recent literature on trauma has identified that despite the suffering associated with it, there are people who report benefits - and such condition is described as post-traumatic growth. Joseph (2011) points out that although people with PTSD report a drop in quality of life, they may also experience post-traumatic growth, defined by him as a transformation process of life meanings and changing of priorities, resulting in a new sense of self and of your own capabilities, with deepening of interpersonal relationships, as there is more proximity to relevant persons. According to this author, research shows that traumatic growth is related to fewer mental health problems, low levels of depression and suicide, and high levels of positivity in a variety of trauma survivors.

Data from this study also indicate that participants with PTSD symptoms experienced its WSEs for a significantly longer period compared to individuals without symptoms. This fact is in accordance with literature data, which point to the influence of duration or chronicity of school aversive events on the traumatic effects thereof (McKenney et al., 2005; Sourander et al, 2009), as the consequences for victims may have cumulative features (Craig \& Pepler, 2003). According to McKenney et al. (2005), in cases of school victimization, many individuals with PTSD can recover on their own, but most need help or have symptoms for longer periods, suggesting the importance of routinely considering the variable "duration" of victimization in school context interventions.

In addition, compared to individuals without PTSD symptoms, those with symptoms had higher rates of school victimization in general (including relational, verbal, physical, and sexual violence, property damage, unfair discipline and witnessing violence). Such statements point out to the importance of studies investigating polyvictimization in the school context to clarify its influence on traumatic symptoms (Finkelhor, Turner, \& Hamby, 2012). According to Felix et al. (2009), polyvictimized students, when compared to individuals who have experienced only one type of victimization or were not victimized at all, are more likely to experience depression, feeling unsafe at school, and poor academic performance. These data demonstrate that, in addition to investigating WSEs, other variables are relevant for understanding the development of PTSD symptoms in school violence victims, such as relevant individual aspects encompassing psychological vulnerabilities (Elwood, Hahn, Olatunji, \& Williams, 2009), and other features, as personal beliefs about the world and about traumatic events, and the role of resilience (Newman et al., 2011).

Therefore, a limitation of this study is the use of only one instrument for data collection, precluding analysis of such individual variables. This study neither addressed traumatic and stressful experiences in students' home and their family support system. It would be important, thus, for future studies to investigate the various factors that could influence PTSD development or maximize its impact.

The sample is not representative of the Brazilian general population of University students, making it difficult to generalize the data. Future studies could use an objective measure of income to facilitate interpretations from such variable. In addition, this was a retrospective study, a methodology that may favor memory biases (forgetfulness, memory distortions). On the other hand, retrospective studies offer the opportunity to investigate long term effects of a traumatic event, providing information on how adults perceive their school experience and how they perceive their impact (Schafer et al., 2004), issues often ignored by 
prospective studies (Kendall-Tackett \& Becker-Blease, 2004). It is also argued, as Brewin, Andrews and Valentine (1993) do, that there is evidence that memories of significant and harmful experiments remain accurate over many years. Memories may be more easily evoked if they were unique (different from everyday content) and unexpected, and people recall more experiences with emotional content with important consequences (Brewin et al., 1993).

Despite these limitations, the data presented by this study may be useful for enriching the literature on school victimization impact. Although it is known that such victimization may cause many harmful effects, little research has described such effects and its prevalence among the victims, especially in Brazil. By indicating the main traumatic symptoms developed by students after victimization in school on the years preceding University, and their perception of distress after such victimization, the study draws attention to the phenomenon of school violence (Williams \& StelkoPereira, 2013), and the need to create or expand educational policies to address the issue. In addition, the results may contribute to the development of prevention and intervention programs focused on school violence, specifically for victims, which may be used in training programs to raise awareness of educators and administrators on the harmful consequences of school victimization. It was possible to identify in the present study, relevant variables associated with traumatic symptoms (the distress level and benefits generated after the experience, the importance of the event's duration, and the modality of school victimization), aspects that could contribute to a better understanding of the Brazilian school violence context.

\section{References}

Albuquerque, P. P. (2014). Trauma e histórico de vitimização na escola: Um estudo retrospectivo com estudantes universitários [Trauma and victimization history at school: A retrospective study with university students] (Doctoral dissertation, Universidade Federal de São Carlos, São Carlos, Brazil). Retrieved from dehttp:// www.bdtd.ufscar.br/htdocs/tedeSimplificado/tde_busca/ arquivo.php? codArquivo=7234

Albuquerque, P. P., \& Williams, L. C. A. (2014). Evidências de validade da escala 'Student Alienation and Trauma survey- R" [Validity evidence of the "Student Alienation and Trauma Survey- R" scale]. Avaliação Psicológica, 13(1), 115-124.

Albuquerque, P. P., Williams, L. C. A., \& D'Affonseca, S. M. (2013). Efeitos tardios do bullying e transtorno de estresse pós-traumático: Uma revisão crítica. [Long term effects of bullying and posttraumatic stress disorder: A literature review]. Psicologia: Teoria e Pesquisa, 29(1), 91-98. doi:10.1590/S0102-37722013000100011

American Psychiatric Association. (2002). Manual diagnóstico e estatístico de transtornos mentais: DSMIV-TR [Diagnostic and statistical manual of mental disorders: DSM-IV-TR] (C. Dornelles, Trans., 4th ed.). Porto Alegre, RS: Artmed.
American Psychiatric Association. (2013). Diagnostic and statistical manual of mental disorders: DSM-5 (5th ed.) Washington, DC: American Psychiatric Association.

Ateah, C., \& Cohen, I. (2009). School victimization and bullying experiences: Cross-national comparisons between Canada and the United States. New Scholarship in the Human Services, 8(1), 1-22.

Bond, L., Carlin, J. B., Thomas, L., Rubin, K., \& Patton, G. (2001). Does bullying cause emotional problems? A prospective study of young teenagers. British Medical Journal, 323(7311), 480-484. doi:10.1136/ bmj.323.7311.480

Brewin, C. R., Andrews, B., \& Gotlib, I. H. (1993). Psychopathology and early experience: A reappraisal of retrospective reports. Psychological Bulletin, 113(1), 8298. doi:10.1037/0033-2909.113.1.82

Craig, W. M., \& Pepler, D. J. (2003). Identifying and targeting risk for involvement in bullying and victimization. The Canadian Journal of Psychiatry, 48(9), 577-582.

Crosby, J. W., Oehler, J., \& Capaccioli, K. (2010). The relationship between peer victimization and posttraumatic stress symptomatology in a rural sample. Psychology in the Schools, 47(3), 297-310. doi:10.1002/ pits.20471

Cubas, V. O. (2007). Violência nas escolas: Como defini-la? [Violence in schools: How to definite it]. In C. Ruotti, R. Alves, \& V. O. Cubas, Violência na escola: Um guia para pais e professores [Violence in school: A guide for parents and teachers] (pp. 23-52). São Paulo, SP: Andhep/Imprensa Oficial do Estado de São Paulo.

Elklit, A., \& Petersen, T. (2008). Exposure to traumatic events among adolescents in four nations. Torture, 18(1), 2-11.

Elwood, L. S., Hahn, K. S., Olatunji, B. O., \& Williams, N. L. (2009). Cognitive vulnerabilities to the development of PTSD: A review of four vulnerabilities and the proposal of an integrative vulnerability model. Clinical Psychology Review, 29(1), 87-100. doi:10.1016/j.cpr.2008.10.002

Fekkes, M., Pijpers, F. I. M., Fridriks, A. M., Vogels, T., \& Verloove-Vanhorick, S. P. (2010). Do bullied children get ill, or do ill children get bullied? A prospective cohort study on the relationship between bullying and health-related symptoms. Pediatrics, 117(5), 1568-1574. doi:10.1542/peds.2005-0187

Felix, E. D., Furlong, M. J., \& Austin, G. (2009). A cluster analytic investigation of school violence victimization among diverse students. Journal of Interpersonal Violence, 24(10), 1673-1695. doi:10.1177/0886260509331507

Figueira, I., \& Mendlowicz, M. (2003). Diagnóstico do transtorno de estresse pós-traumático. [Post-traumatic stress disorder diagnosis]. Revista Brasileira de Psiquiatria, 25(supl.1), 12-16. doi:10.1590/S151644462003000500004

Finkelhor, D., Turner, H. A., \& Hamby, S. (2012). Let's prevent peer victimization, not just bullying. Child Abuse \& Neglect, 36(4), 271-274. doi:10.1016/j.chiabu.2011.12.001

Gini, G., \& Pozzoli, T. (2009). Association between bullying 
and psychosomatic problems: A meta-analysis. Pediatrics, 123(3), 1059-1065. doi:10.1542/peds.2008-1215

Hemphill, S. A., Kotevski, A., Herrenkohl, T. I., Bond, L., Kim, M. J., Toumbourou, J. W., \& Catalano, R. F. (2011). Longitudinal consequences of adolescent bullying perpetration and victimisation: A study of students in Victoria, Australia. Criminal Behaviour and Mental Health, 21(2), 107-116. doi:10.1002/cbm.802

Houbre, B., Tarquinio, C., Thuillier, I., \& Hergott, E. (2006). Bullying among students and its consequences on health. European Journal of Psychology of Education, 21(2), 183-208. doi:10.1007/BF03173576

Hyman, I. A., \& Snook, P. A. (2002). My Worst Experience Scales (MWES): Manual. Torrance, CA: WPS.

Idsoe, T., Dyregrov, A., \& Idsoe, E. C. (2012). Bullying and PTSD symptoms. Journal of Abnormal Child Psychology, 40(6), 901-911. doi:10.1007/s10802-012-9620-0

Joseph, S. (2011). What doesn't kill us: The new psychology of posttraumatic growth. Philadelphia, PA: Basic Books.

Kay, B. R. (2005). A cross-national study of bullying experienced by British and American schoolchildren: Determining a typology of stressors and symptoms (Unpublished doctoral dissertation). Temple University, Philadelphia, PA.

Kendall-Tackett, K., \& Becker-Blease, K. (2004). The importance of retrospective findings in child maltreatment research. Child Abuse \& Neglect, 28(7), 723-727. doi:10.1016/j.chiabu.2004.02.002

Kessler, R. C., Sonnega, A., Bromet, E., Hughes, M., \& Nelson, C. B. (1995). Posttraumatic stress disorder in the National Comorbidity Survey. Archives of General Psychiatry, 52(12), 1048-1060. doi:10.1001/ archpsyc. 1995.03950240066012

Kristensen, C. H., Parente, M. A. M. P., \& Kaszniak, A. W. (2005). Transtorno de estresse pós-traumático: Critérios diagnósticos, prevalência e avaliação. [Post-traumatic stress disorder: Diagnostic criteria, prevalence and evaluation]. In R. M. Caminha (Org.), Transtornos do estresse pós-traumático (TEPT): Da neurobiologia à terapia cognitiva [Post-traumatic stress disorder (PTSD): Neurobiology to cognitive therapy] (pp. 15-35). São Paulo, SP: Casa do Psicólogo.

Lipschitz, D. S., Rasmusson, A. M., Anyan, W., Cromwell, P., \& Southwick, S. M. (2000). Clinical and functional correlates of posttraumatic stress disorder in urban adolescent girls at a primary care clinic. Journal of the American Academy of Child and Adolescent Psychiatry, 39(9), 1104-1111. doi:10.1097/00004583-20000900000009

Luukkonen, A., Rasanen, P., Hakko, H., \& Riala, K. (2010). Bullying behavior in relation to psychiatric disorders and physical health among adolescents: A clinical cohort of 508 underage impatient adolescents in Northern Finland. Psychiatry Research, 178(1), 166-170. doi:10.1016/j. psychres.2010.04.022

McGuckin, C., Lewis, C. A., Cummins, P. K., \& Cruise, S. M. (2011). The stress and trauma of school victimization in Ireland: A retrospective account. Psychology, Society \& Education, 3(1), 55-67.

McKenney, K. S., Pepler, D. J., Craig, W. M., \& Connoly, J. A. (2005). Psychosocial consequences of peer victimization in elementary and high school: An examination of posttraumatic stress disorder symptomatology. In K. A. Kendall-Tackett \& S. M. Giacomoni (Eds.), Child victimization: Maltreatment, bullying and dating violence, prevention and intervention (pp. 15-2-15-17). Kingston, NJ: CRI.

Mynard, H., Joseph, S., \& Alexander, J. (2000). Peervictimisation and posttraumatic stress in adolescents. Personality and Individual Differences, 29(5), 815-821. doi:10.1016/S0191-8869(99)00234-2

Newman, M. L., Holden, G. W., \& Delville, Y. (2011). Coping with the stress of being bullied: Consequences of coping strategies among college students. Social Psychological and Personality Science, 2(2), 205-211. doi:10.1177/1948550610386388

Orpinas, P., \& Horne, A. M. (2006). Bullies and victims: A challenge for schools. In J. R. Lutzker (Ed.), Preventing violence: Research and evidence-based intervention strategies (pp. 147-165). Washington, DC: American Psychological Association.

Ozer, E. J., Best, S. R., Lipsey, T. L., \& Weiss, D. S. (2003). Predictors of posttraumatic stress disorder and symptoms in adults: A meta-analysis. Psychological Bulletin, 129(1), 52-73. doi:10.1037/0033-2909.129.1.52

Salter, E., \& Stallard, P. (2008). The psychological impact of traumatic events on children. Psychological Injury and Law, 1(2), 138-146. doi:10.1007/s12207-008-9014-3

Schaefer, L. S., Lobo, B. O. M., \& Kristensen, C. H. (2012). Reações pós-traumáticas em adultos: Como, por que e quais aspectos analisar? [Post-traumatic reactions in adults: How, why and which aspects analyze?]. Temas em Psicologia, 20(2), 459-478. doi:10.9788/TP2012.2-14

Schafer, M., Korn, S., Smith, P. K., Hunter, S. C., MoraMerchán, J. A., Singer, M. M., \&Van der Meulen, K. (2004). Lonely in the crowd: Recollections of bullying. British Journal of Developmental Psychology, 22(3), 379-394. doi:10.1348/0261510041552756

Sourander, A., Ronning, J., Brunstein-Klomek, A., Gyllenberg, D., Kumpulainen, K., Niemelä, S., . . . Almqvist, F. (2009). Childhood bullying behavior and later psychiatric hospital and psychopharmacologic treatment: Findings from the Finnish 1981 birth cohort study. Archives of General Pyschiatry, 66(9), 1005-1012. doi:10.1001/archgenpsychiatry.2009.122

Stelko-Pereira, A. C., Santini, P. M., \& Williams, L. C. A. (2011). Punição corporal aplicada por funcionários de duas escolas públicas brasileiras. [Corporal punishment applied by employees of two Brazilian public schools]. Psicologia em Estudo, 16(4), 581-591. doi:10.1590/ S1413-73722011000400009

Storch, E. A., \& Esposito, L. E. (2003). Peer victimization and posttraumatic stress among children. Child Study Journal, 33(2), 91-98. 
Williams, L. C. A., \& Stelko-Pereira, A. C. (Orgs.). (2013). Violência nota zero: Como aprimorar as relações na escola. [Violence grade zero: Enhancing relations at school]. São Carlos, SP: EdUFSCar/FAPESP.

Williams, L. C. A., D'Affonseca, S. M., Correia, T. A., \& Albuquerque, P. P. (2011). Efeitos a longo prazo de vitimização na escola. [Long-term effects of victimization at school]. Gerais: Revista Interinstitucional de Psicologia, 4(2), 187-199.

Paloma Pegolo de Albuquerque has a Ph.D. in Psychology from Universidade Federal de São Carlos.

Lucia C. A. Williams is Professor of Psychology at the Universidade Federal de São Carlos.

Received: Aug. 13, 2014

1st Revision: Mar. 4, 2015

Approved: Apr. 7, 2015

How to cite this article:

Albuquerque, P. P., \& Williams, L. C. A. (2015). Impact of the worst school experiences in students: A retrospective study on trauma. Paidéia (Ribeirão Preto), 25(62), 343351. doi:10.1590/1982-43272562201508 